\title{
Descriptive Study of Adolescent Depression in Covid-19 Pandemic
}

\author{
Naomi Soetikno ${ }^{1, *}$ \\ ${ }^{1}$ Faculty of Psychology, Tarumanagara University, Jakarta 11440, Indonesia \\ ${ }^{*}$ Corresponding author. Email: naomis@fpsi.untar.ac.id
}

\begin{abstract}
Covid-19 virus is a respiratory disease that can spread from person to person. The impact of the existence of the Covid-19 pandemic in various sectors of social life. Another impact with the physical distance between one person and another is that many office agencies and schools have closed their activities in direct contact. The phenomenon was found that adolescents showed psychological problems namely depression during the Covid19 pandemic. This study aims to obtain a description of the factors that drive depression in adolescents during the Covid-19 pandemic. The study was conducted on three teenagers aged 15-18 years who were obtained by purposive sampling method. Participants filled out the Depression Anxiety Stress Scale (DASS-42) questionnaire to determine the level of depression experienced, then proceed with the interview. The results showed that there were things that were shared between the three participants, namely the limitations in socializing, lack of space in playing or doing activities, as well as doubts about the future. The results of this study are useful for parents and for the development of further studies.
\end{abstract}

Keywords: Depression, Adolescents, Pandemic Covid-19

\section{INTRODUCTION}

At the beginning of 2020, the whole world experienced health problems that were so fast spreading, the Covid-19 virus. Covid-19 virus is a respiratory disease that can spread from person to person. Covid-19 is part of a coronavirus that was first discovered in Wuhan, China [1]. Most people infected with the Covid-19 virus will experience mild to moderate respiratory disease and recover without special treatment. Whereas older people who have cardiovascular disease, diabetes, chronic respiratory diseases, and cancer are more likely to develop serious diseases [2].

The World Health Organization (2020) explains that "the Covid-19 virus can spread through droplets of saliva or fluid that comes out when people are infected with coughing or sneezing. There is currently no vaccine or special treatment for Covid-19 ". Already more than 60,000 people have been infected with Covid-19 worldwide [3]. The spread of the Covid-19 virus has entered Indonesian territory as well [4]. At present the total number of confirmed cases of Covid-19 in Indonesia as of June 6, 2020 , is 29,521 , with 1,770 death cases, 9,443 cured cases, and 18,308 treatment cases. The list of Covid-19 infected countries is increasing every day following the development of data and information obtained.

Efforts made by all governments in the world as well as WHO in getting treatment and antiviral have not also shown a bright spot. Until now there is no vaccine and also treatment to treat Covid-19. The best way is with daily prevention. World Health Organization (2020) calls for efforts to prevent the transmission of Covid-19. The way to prevent and slow down transmission is by frequent hand washing or using alcohol, not touching your face and protecting yourself from others. One way to protect yourself from others is by maintaining physical distance. Maintaining physical distance from others means keeping a distance from others when outside the home, avoiding crowds, avoiding group gatherings, and at least 6 feet or two meters away.

The impact of the existence of the Covid-19 in various sectors of social life. The DKI Jakarta Manpower, Transmigration and Energy Office noted that 162,416 workers in Jakarta had been laid off and laid off without pay as a result of Covid-19 [5]. It is known in detail that 30,137 workers from 3,348 companies were laid off, while 132,279 workers from 14,697 companies were laid off without pay. Of course this will have an impact on the psychological condition of individuals who receive termination of employment.

Another impact with the physical distance between one person and another is that many office agencies and schools have closed their activities in direct contact. Many activities are carried out to move from home. Dr. Steven Gordon [6] states that quarantine and isolation are effective ways to protect the community. Quarantine is to keep someone who might be displayed Covid-19 from another person, separate from others, restricting movement outside the home. Whereas isolation is used to separate sick people from healthy people, those who are sick must stay at home and when at home must separate themselves from others who live at home. 
Prolonged social isolation turns out to cause psychological problems, namely depression. Feeling alone, helpless, hopeless, and worried that something bad will happen is a common symptom of depression [7]. Social isolation is a state of alienation, where social connections are limited or even non-existent [8]. Social isolation consists of two namely objective social isolation and subjective social isolation [9]. Objective social isolation is physical separation from and absence or lack of interaction with others, which includes assessing the size of one's social network, frequency of interaction with members of social networks, and participation in groups, voluntary, or other social activities / activities.

Subjective social isolation is defined as the perception and quality of individual relationships with members of their social networks, as well as perceived integration and involvement in social networks. Objective and subjective social isolation related to mental health problems and loneliness. Feelings of loneliness and depression often arise when social relationships are not fulfilled. Loneliness can adversely affect a person's physical, mental and cognitive health [10].

Social relationships are a fundamental part of human life. Social relationships can provide support, meaning and influence health. Many people will experience stress reactions, anxiety, and depression [11]. This impact is also evident for people with mental health disorders, especially for those who struggle with anxiety and depression [12]. With social isolation occurring during quarantine during the pandemic, adverse health consequences include depression, poor sleep quality, impaired executive function, accelerated cognitive decline, poor cardiovascular function and impaired immunity at every stage of life. Singer (2018) states that the risk of depression is higher in those who come in direct contact with children, family, or friends less than once a month [13]. People with contact once or twice a week have the lowest levels of depression. The current pandemic has a great risk of psychological and psychiatric morbidity [14]. The human body is not designed to handle social deprivation for too long, because solitude and no social opportunities can cause depression [15].

It cannot be denied the fact that individuals who were depressed during the Covid-19 pandemic, such as a student from China who lives in Saudi Arabia committed suicide by jumping from the 3rd floor of a hospital. With the quarantine due to being suspected of being infected with coronavirus, it has already taken the life of a student [16]. There is also another teenager, Emily Owen, 19, the youngest (UK) suicide victim who is afraid of isolation due to the lockdown announcement, as reported by Miller, 2020 in the New York Post [17].

Young age, especially teenagers need more attention because it is related to the stages of development and their vulnerability to experience mental problems. At the stage of adolescent development, usually they have shown more mature cognitive development. They tend to do a long process of thinking such as seeing rationality and logic when formulating an opinion [18].

In the Covid-19 pandemic, with many restrictions on direct interaction, it greatly affected teenagers. Teenagers will search from various media sources that they are able to meet to find information. The media can also be a source of anxiety for teenagers. This is because teenagers still have difficulty in determining whether the content in the media is true and can be trusted. Parents as the closest source of information during a pandemic can also backfire for teenagers if there is inaccurate information. So many articles in the world that provide tips on how to deliver appropriate information related to the pandemic Covid-19 [19].

Of the many phenomena associated with the impact of the Covid-19 pandemic to adolescents so that it can lead to mental health disorders namely depression, the researchers conducted research to determine the dynamics of the problem that triggered depression in adolescents during the Covid-19 pandemic.

\section{LITERATURE REVIEW AND RESEARCH METHODS}

\subsection{Depression}

Depression is a common and serious mental disorder, which can negatively affect feelings, ways of thinking, and ways of acting. This can cause a variety of emotional and physical problems, and can reduce a person's ability to function at work or at home [20]. Depression is characterized by feelings such as sadness, loss of interest or pleasure in daily activities, low energy and loss of concentration [21]

According to the World Health Organization (2020), depression can be caused by several factors, such as biological, psychological, and social factors (such as unemployment, mourning, and psychological trauma). Depression is caused by genetic, hormonal and chemical factors in the brain, but depression is also influenced by environmental stress [22]. Depression can cause dysfunction and worsen the life situation of people with depression.

Depression can be caused by several factors, such as; (a) biological factors, i.e. differences in chemicals in the brain; (b) genetic factors, i.e. depression that can occur because family members have previously been depressed; (c) psychological / personality, individuals who are dependent, not assertive, have low self-esteem can be overwhelmed by stress and pessimistic which can cause depression; (d) environmental factors, individuals who are continuously exposed to violence, neglect, harassment, or poverty.

Depression can also be caused by cognitive distortion. Baron et al [23], said that depression is always associated with cognitive distortion. Beck said "A similar experience will affect two people in different ways. This difference is greatly influenced by the perspective of the individual concerned about an event. The perspective or interpretation of cognition that is often mistaken is involving negative distortions of life experiences, negative self-assessment, 
pessimism, and hopelessness ". The negative views learned subsequently lead to feelings of depression.

Burn [23] explains that it is not an actual event, but selfperception that results in mood swings. Emotions that arise are caused by the way a person sees things. In depressed individuals, the thoughts that arise will always be things that are illogical, turned around, not realistic about negative events. This is because their understanding of what happened is not right, not based on objective facts, but rather based on emotions that are happening.

Generally individuals who are depressed show typical physical, psychological and social symptoms. Some people show minimal symptoms, some others more. High and low symptoms vary from time to time. According to the Diagnostic and Statistical Manual 5 (DSM-5), depressive disorders can be established if at least 5 of the symptoms below have been found within the same 2 week period and are a change in the pattern of function from before. The following are common symptoms and signs of depression:

Physical symptoms such as (1) Sleep disturbance; Difficulty sleeping (insomnia) or excessive sleep (hypersomnia), (2) Decreased level of activity, for example, loss of interest, enjoyment of a hobby or activity that was previously favoured, (3) Difficulty eating or overeating (can become thin or overweight), (4) Slowing thoughts and reduced physical movement (can be observed by others, not just subjective feelings of anxiety or slowed down), (5) Fatigue or loss of energy almost every day, (6) Difficulty concentrating, remembering, deciding.

On the other side, here is the Psychological Symptoms, such as (1) Feeling sad, anxious, or continuous emptiness, (2) Feeling hopeless and pessimistic, (3) Guilt, worthlessness, feeling overwhelmed and helpless / useless, (4) Not calm and easily offended, (5) Thinking about dying or committing suicide, (6) Loss of confidence.

The social symptom such as (1) Decreased daily activities and interests (withdrawing, aloof, lazy), (2) There is no motivation to do anything, (3) Loss of desire for life and suicidal ideation, (4) Disrupting education and employment.

\subsection{Method}

The method used in this research is qualitative information collection on 3 teenagers aged 15-18 years. Collecting information about the problems that lead to depression in adolescents begins with asking teens to fill in the questionnaire Depression Anxiety Stress Scale (DASS42) developed by Lovibond and Lovibond (1995) which consists of 42 items. DASS is distributed through Google forms to researchers' social networks. By using purposive sampling, participants were obtained in this study. DASS items contain symptoms of depression, anxiety, and stress. DASS items contain symptoms of depression, anxiety, and stress. Internal consistency for DASS-42 ranges from 0.92 - 0.97 for the 3 dimensions: 1). Depression, 2). Anxiety, and 3). Stress [24]. Three teenage participants who had high
DASS scores were contacted to explore more about the problems that led to depression.

\section{RESULT}

Of the three participants obtained through the DASS questionnaire, subjects $X$, female, 15 years old, 10th grade high school in Bandung; subject Y, female, 18 years old, 12th grade of high school in Bandung; and subject $Z$, male, 18 years old, 12th grade high school in Jakarta. Interviews were conducted through online video call media in AprilMay 2020.

From the results of interviews conducted with subject $\mathrm{X}$, obtained some information related to factors that encourage depression to her. Subject $X$ showed a lackadaisical behavior, while having to go through an online class also felt physical fatigue that was said by subject $\mathrm{X}$ that she did not know the cause. Subject X said that her sleep became less regular, like at night it would be very late at night and then she could fall asleep. Usually during pandemic subject $X$ will watch a movie, up to 4 films a day. When asked about her appreciation of the online class at home during this pandemic, subject $\mathrm{X}$ said she was rather lazy to follow her but was forced to follow because she was told by her parents. When the online class took place, subject $X$ actually liked meeting with the teacher and some of her friends. According to subject $\mathrm{X}$ there is no problem in the learning process. According to subject $X$, the most problematic during this pandemic, were activities confined to the home, subject $\mathrm{X}$ felt bored. Judging from the family background and settings in the house, it is known that subject $\mathrm{X}$ is the first child of two siblings, her younger brother is a 12 year old. Both parents of subject X work normally, but during this pandemic the mother in particular is always at home while the father sometimes works out of the house. In the house, the subject $\mathrm{X}$ activities besides studying online classes, watching movies, sleeping, and sometimes asked by the mother to help drying and folding clothes. This activity was actually rarely carried out by subject $\mathrm{X}$ before, but in the pandemic period it was felt by subject $\mathrm{X}$ that many mothers told her to do chores helping household matters.

The activity of taking care of the household which is rarely carried out by subject $\mathrm{X}$, as well as the lack of play areas outside the home, seems to be a problem complained of by subject $X$.

In contrast to subject $Y$, from the results of the DASS it was found that there were complaints about doubts about the final exam of the 12th grade high school that she was undergoing. Subject Y said that she should undergo the final high school graduation exams and want to be like her older siblings. The background picture of subject $\mathrm{Y}$ is the third of four children. Subject $\mathrm{Y}$ was upset and disappointed because of this pandemic so many changes experienced in her life, and it did not make her comfortable. Subject Y is currently also in a dating relationship, which according to her before the pandemic there were still times when she could meet her boyfriend who happened to be a schoolmate but had different classes. At the time of this pandemic, the 
mother of subject $\mathrm{Y}$ was quite authoritarian according to subject $\mathrm{Y}$, so she was not permitted to travel including meeting with her boyfriend. Subject Y felt lonely without her boyfriend, because according to her all this time the place where she was told was her boyfriend. Subject Y felt she was not close to his brothers and sisters. The activity of her older brother and younger brother is also playing games all day during this pandemic, while subject Y prefers to watch movies and sometimes draw. Subject Y had hopes that this pandemic would end soon because she wanted to enroll in college according to her intended field of accounting economics, but subject $\mathrm{Y}$ also felt doubtful. Subject $Y$ was doubtful whether the department was right for her and in fact at this time her interest in learning also declined somewhat.

From the complaints of subject $\mathrm{Y}$, it seems that the factor influencing subject $\mathrm{Y}$ to have a depressive mood is due to the lack of opportunities to socialize and explore the environment. Things that can be done by subject $\mathrm{Y}$ in socializing with her boyfriend and friends becomes very limited. Exploration of the environment is also a factor that makes the existence of a depressive atmosphere felt by subject Y. Subject Y cannot find out about the campus and course of study she will choose.

In subject $Z$, depressive moods were also reflected in the results of the DASS. Subject $Z$ is very lacking in the initiative to carry out tasks in his home. Fighting is quite common between subject $Z$, his younger sister, also with his mother and father. Subject $Z$ felt the level of quarrel with the family more and more often during this pandemic. According to subject $\mathrm{Z}$, things that often make a quarrel occur because subject $\mathrm{Z}$ feels disturbed in doing the preferred activity which is playing games. Subject $Z$ felt that during this pandemic, he had a lot of time to increase the score of the online games he played frequently. During the period before the pandemic, subject $\mathrm{Z}$ also often played online games, but was often reprimanded by his mother and reminded to do schoolwork. During this pandemic, subject $\mathrm{Z}$ did not do too much school work because he was just waiting for his final exam and graduation. Subject $Z$ was quite enthusiastic about discussing high school graduation because according to him this was an opportunity so he could immediately study outside the city as he had planned. With this pandemic condition, in fact subject $\mathrm{Z}$ also had doubts about his future, regarding the course he would choose. Subject $\mathrm{Z}$ calculated that his father's finances were also running low because as a printing entrepreneur, his father's business when the pandemic was deserted.

From interviews with subject $\mathrm{Z}$, what can be concluded is that even a limited social scope can be transferred to online gaming activities. Subject $\mathrm{Z}$ also has doubts about the future due to a pandemic.

\section{CONCLUSION}

Based on the results of interviews conducted with three teenage participants aged 15-18 years, problems were felt as a factor that influenced the depressive mood in adolescents. Some things that were shared by the three participants were limitations in socializing, lack of space to play or do activities, and doubts about the future. In line with the opinion of Parekh, 2017 that the factors that contribute to depression are (a) biological factors, (b) genetic factors, (c) psychological / personality factors, and (d) environmental factors, it can be explained that participants in this study also showed that psychological or personality factors of those who create a depressed atmosphere are felt. Z's personality is easily upset and quarreling with his family, subject $\mathrm{Y}$ is dependent with her friends and boyfriend, and subject $\mathrm{X}$ 's personality is dependent and needs to be directed. Environmental factors are also the cause of the depressive perceived by participants, namely the home environment that limits the space for movement and the socio-economic environment in the pandemic that causes doubts about the future.

From the results of this study, what can be practical advice is for parents who currently have more time with teenagers. The pattern of care provided for adolescents is to involve them more in activities with understanding and explanation. Practical advice for further research is to review this depressive problem longitudinally, so that it can be seen more clearly about the psychological dynamics of adolescents that show depressive moods in a period of time that is quite long pandemic.

\section{REFERENCES}

[1] Center Disease Control. (2020, April 4). Coronavirus Disease 2019 (Covid-19). Retrieved from https://www.cdc.gov/coronavirus/2019ncov/prevent-getting- sick/socialdistancing.html

[2] World Health Organization (2020). Coronavirus disease (Covid-19) advice for the public. Retrieved from https://www.who.int/emergencies/diseases/nov el-coronavirus-2019/advice-for-public

[3] Yao, H., Chen, J.H., Xu, Y.F. (2020) Patients with mental health in the covid-19 epidemic. The Lancet Psychiatry, vol 7 . doi:10.1016/S2215-0366(20)30090-0

[4] Idhom, A. M.(2020). Update corona 2 April 2020: data covid-19 Indonesia dan dunia terbaru. Retrieved from : https://tirto.id/updatecorona-2-april-2020-data-covid-19-indonesiadunia-terbaru-eKrg

[5] Sari, A. (2020). PHK Massal di Tengah Pandemi Covid-19 dan Upaya Pemerintah Berikan Insentif. Retrieved from https://megapolitan.kompas.com/read/2020/04/ 06/06231941/phk-massaldi-tengah-pandemicovid-19-dan-upaya-pemerintah-berikan on 7 April 2020 
[6] Health essentials (2020). Covid-19 understanding quarantine, isolation and social distancing in a pandemic. Retrieved from: https://health.clevelandclinic.org/covid-19understanding-quarantine-isolation-and-socialdistancing-in-a-pandemic/

[7] Ao, B.(2020). Unemployment, isolation and depression from COVID-19 may cause more 'deaths of despair'. Retrieved from: https://medicalxpress.com/news/2020-06unemployment-isolation-depression-coviddeaths.html

[8] Matthews, T., Danese, A., Wertz, J., Odgers, C.L., Ambler, A., Moffitt, T.E., Arseneault, L.(2016). Social isolation, loneliness and depression in young adulthood: a behavioural genetic analysis. Social Psychiatry and Psychiatric Epidemiology, vol 51, p.339-348. Doi : 10.1007/s00127-016-1178-7

[9] Taylor, H.O., Taylor, R.J., Nguyen, A.W., \& Chatters, L.(2016). Social isolation, depression, and psychological distress among older adults. Journal of Aging and Mental Health, vol. 3(2), p.229-246. doi: 10.1177/0898264316673511

[10] Novotney, A. (2019The risk of social isolation. Bulletin of American Psychological Association, vol 50 (5), p.32

[11] Quebec. (2020). Situation of the coronavirus (covid-19) in quebec. Retrieved from: https://www.quebec.ca/en/health/healthissues/a-z/2019-coronavirus/situationcoronavirus-in-quebec/

[12] Lohmann, R.C. (2020). Coping with anxiety and depression during the coronavirus pandemic. Retrieved from: https://health.usnews.com/wellness/forparents/articles/coping-with-anxiety-anddepression-during-the-coronavirus-pandemic

[13] Singer, C. (2018). Health effects of social isolation and loneliness. Journal of Aging Life Care. Retrieved from: https://www.aginglifecarejournal.org/healtheffects-of-social-isolation-and-loneliness/

[14] Sood, S. (2020). Psychological effects of the coronavirus disease-2019 pandemic. Research \& Humanities in Medical Education, 7, 23-26 Retrieved from https://www.rhime.in/ojs/index.php/rhime/artic le/view/264

[15] Kanter, J., \& Manbeck, K. (2020). Covid-19 could lead to an epidemic of clinical depression, and the health care system isn't ready for that, either. Retrieved from: http://theconversation.com/covid-19-couldlead-to-an- epidemic-of-clinical- depression-and-the-health-care-system-isntready- for-that-either- 134528

[16] Chinese student commits suicide in Saudi after being quarantined for coronavirus. February 17 2020. Retrieved from: https://www.middleeastmonitor.com/20200217 -chinese-student-commits-suicide-in-saudiafter-being-quarantined-for-coronavirus/

[17] Joshua Rhett Miller (2020) British teen dies after suicide attempt due to coronavirus fears. Retrieved from: https://nypost.com/2020/03/25/british-teendies-after-suicide-attempt-due-to-coronavirusfears/

[18] Marotz, L. R., \& Allen, K. E. (2012). Developmental Profiles Pre-Birth through Adolescence, Seventh Edition. USA: Wadsworth Cengage Learning.

[19] American Psychiatric Association (2013) Diagnostic and Statistical Manual of Mental Disorder. Arlington, VA, American Psychiatric Association

[20] Parekh, R (2017) What is depression?. Bulletin of American Psychiatric Association.

Retrieved

from: https://www.psychiatry.org/patientsfamilies/depression/what-is-depression

[21]Fernandez, M., Rodriguez-Barreto, O., Buendia-Roldan, I., Alberti, M., Caro, F., Ipuche, F., Miranda, A., \& Paulin, F.(2019). Prevalence of anxiety and depression and their relationship with clinical characteristics in patients with interstitial lung disease. Journal of Gerontology \& Geriatric Research, vol 8 (4)

[22] Ng, C.W.M., How, C.H., Ng, Y.P.(2017).Managing depression in primary care. Singapore Medical Journal, vol 58 (8), 459-466. Doi:10.11622/smedj.2017080

[23] Sulistyorini,W., \& Sabarisman, M. (2017). Depresi: Suatu tinjauan psikologis. Kesejahteraan Sosial, vol 3 (2)

[24] Said, W., Atmodiwirjo, E.T. \& Soetikno, N. (2020) Dynamics of Emotion in Adolescence with Depression and Anxiety: The Role of Emotional Attachment, Emotional Awareness, and Emotional Regulation. Tarumanagara International Conference on the Applications of Social Sciences and Humanities (TICASH 2019), Atlantis Press Publisher 